ACADEMIA ROMÂNĂ

Revue Roumaine de Chimie

http://web.icf.ro/rrch/
Rev. Roum. Chim.,

2019, 64(1), 5-17

Doi: $10.33224 /$ rrch.2019.64.1.01

Review

\title{
METAL BASED DRUGS AND CHELATING AGENTS AS THERAPEUTIC AGENTS AND THEIR ANTIMICROBIAL ACTIVITY
}

\author{
Muhammad Imran DIN, Faisal ALI and Azeem INTISAR* \\ Institute of Chemistry, University of the Punjab, Lahore-54590, Pakistan.
}

Received June 29, 2017

In this article, the role of metal complexes and chelating agents as therapeutic agents was reviewed. These agents are employed for the treatment of many hazardous diseases such as cancer, ulcer, anemia, microbial infection etc. Therefore, this article is a mini-review to discuss and focus on the importance of metallodrugs and their curative benefits as a remedy against various diseases. Different therapeutic agents have been described such as chelates of platinum, iron, iridium, rhodium, ruthenium, palladium, cobalt, and nickel.

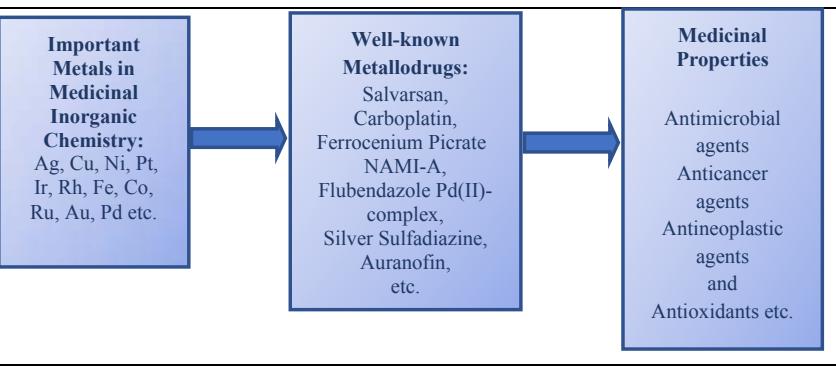

\section{INTRODUCTION}

Metal based drugs have a long history of being used as important therapeutic agents. ${ }^{1}$ Most com- monly used metals employed in various fields of medicinal inorganic chemistry especially as therapeutic agents, are highlighted in Figures 1-2.,
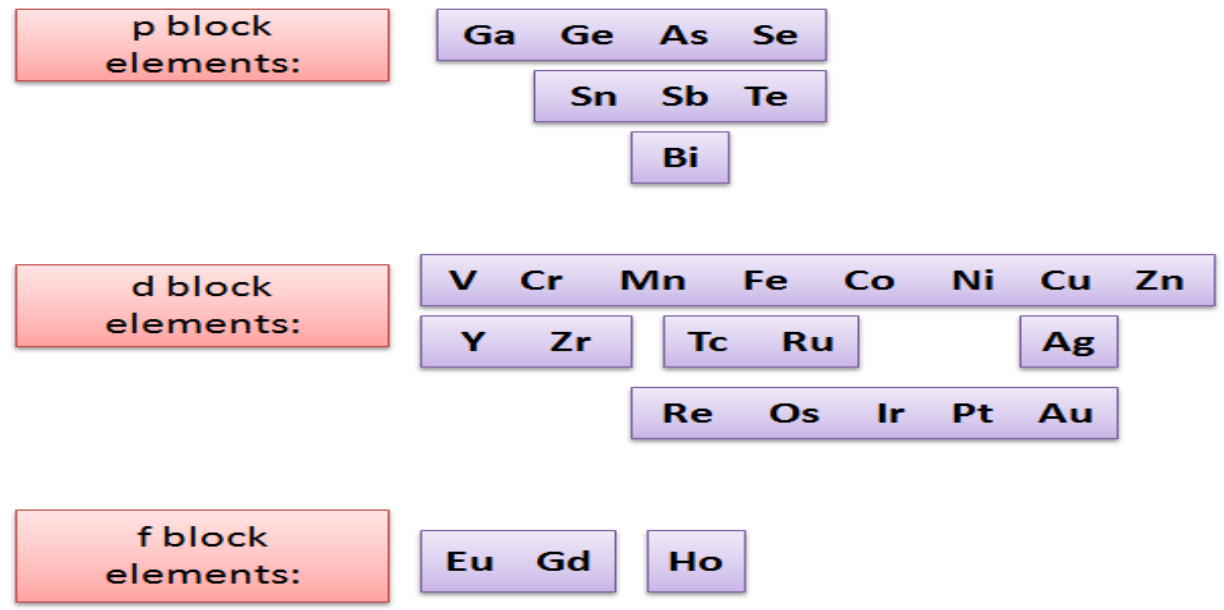

Fig. 1 - Metals employed in medicinal inorganic chemistry.

\footnotetext{
* Corresponding author: azeemchemist@yahoo.com; azeemintisar.chem@pu.edu.pk; Cell: +923344160636
} 


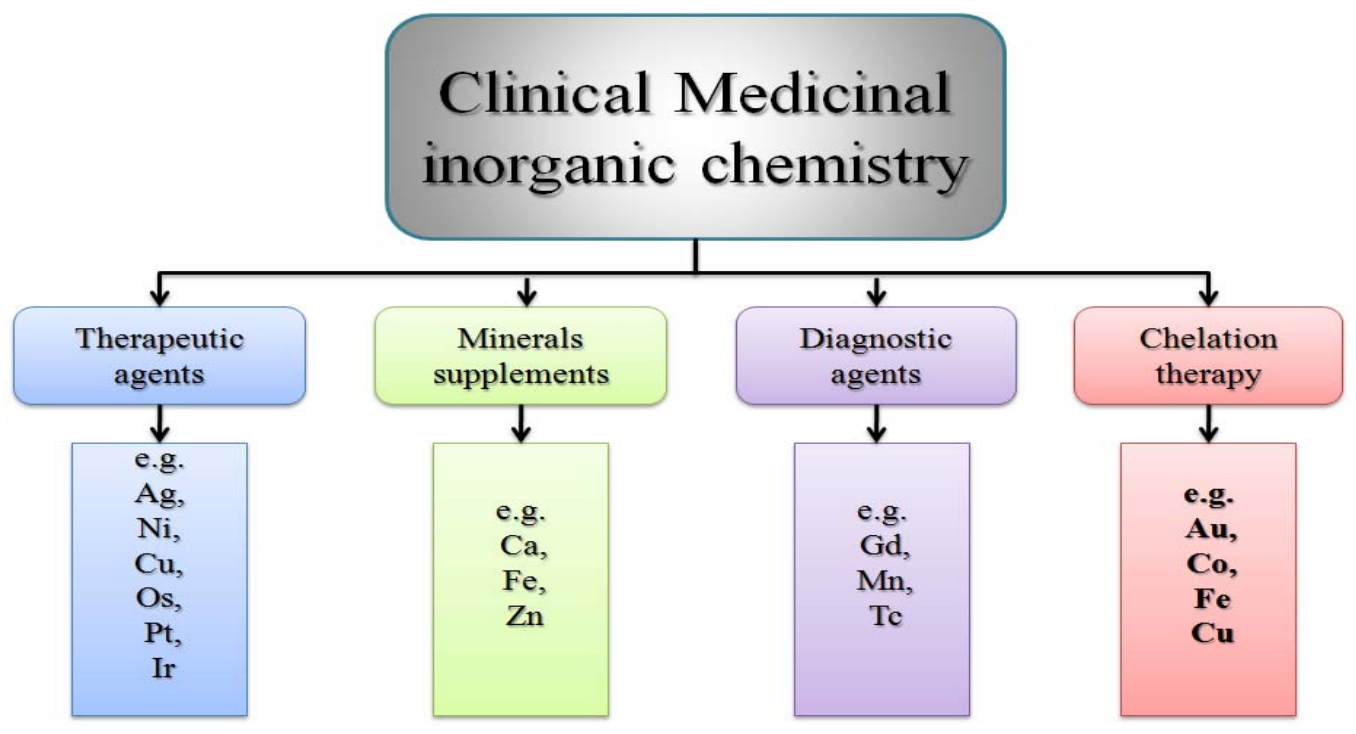

Fig. 2 - Classification of medicinal inorganic chemistry.

Therapeutic agents:<smiles>Nc1cc([As]2S[As](c3ccc(O)c(N)c3)S2)ccc1O</smiles>

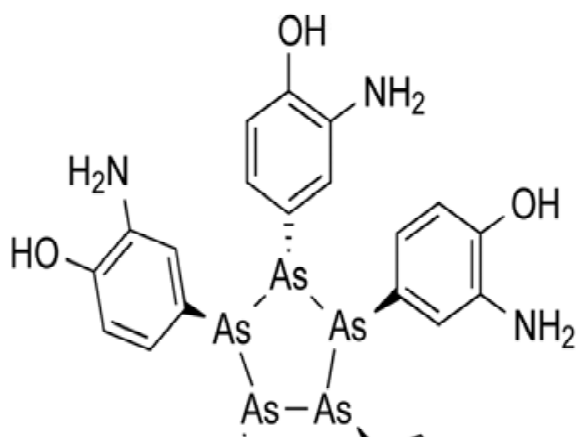

Cyclic model for salvarsan<smiles>N[Pb](N)(Cl)Cl</smiles>

Cisplatin

Fig. 3 - Common and well-known therapeutic metallodrugs.<smiles>O=C1O[PH]2(N[C@H]3CCCC[C@H]3N2)OC1=O</smiles>

Oxaliplatin<smiles>N[PH]1(N)OC(=O)C2(CCC2)C(=O)O1</smiles>

Carboplatin

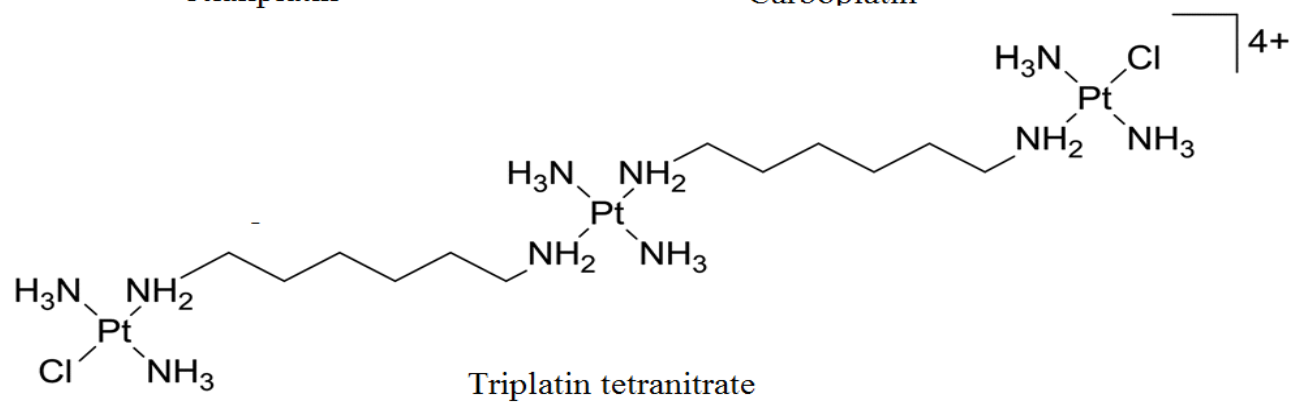

Fig. 4 - Various platinum complexes used as therapeutic agents. 
For many decades, metal particles had been used as vital and significant part in biological sciences. ${ }^{4}$ Medicinal inorganic chemistry defines the field in which either diagnosis or therapy of disease is performed by the application of metal complexes and chelates. ${ }^{5}$ On the other hand, metal ions are useful in the field of biochemistry where these are injected in biological systems and this type of introduction in human body has proved to be highly beneficial for therapeutic purposes. ${ }^{6}$ Figure 3 presents some fruitful and known meditational therapeutic metallodrugs.

Now-a-days, many contrast agents that contain radioactive metal isotopes are being produced. These contrast agents are employed in a single photon emission computed tomography (SPECT) scans in hospitals of various countries worldwide [(SPECT)]. Metal ions, especially $\mathrm{Gd}^{3+}$ are utilized in Magnetic Resonance Imaging (MRI). In the recent past, many MRI and SPECT scans have been performed. In Canada from 2011 to 2012 over 63,000 PET, over a million SPECT and 1.7 million MRI scans were carried out and these numbers are increasing internationally. ${ }^{7}$ These techniques have been used in the treatment of cardiovascular disease, atherosclerosis and malignant tumor growth in human body. So, such imaging agents open new doors in the field of research where one example of this is determining the activity of brain. Salvarsan is the first ever developed therapeutic metallodrug and was elaborated by Paul Ehrlich. It is a mixture of 3-amino-4-hydroxyphenyl-arsenic (III). It is an antimicrobial agent and its main constituent is arsenic. He reported his experimental results of salvarsan on treatment of syphillis in 1912. ${ }^{8}$ Enrlich's Magic Bullets idea was strengthened by salvarsan which was used against various diseases and proved helpful for killing many infectious microorganisms without disturbing the host. ${ }^{9}$ Salvarsan is extensively used by humans but its composition is still not known. Before World War II salvarsan was used in syphilis but later penicillin replaced salvarsan. ${ }^{10}$ The modern chemotherapy was born as a result of wide use of salvarsan and it is regarded as the start of contemporary research. It is very helpful in the development of metallodrugs. In 1965 at Michigan State University Loretta Van Camp and Barnett Rosenberg serendipitously discovered cisplatin, also known as Platinol, while studying Escherichia coli under the effect of electric current, ${ }^{11}$ the structure of which is shown in Figure 3. Platinum electrode emitted cis-diamminedichloroplatinum(II) and were used to inhibit the cell division. ${ }^{11,} 12$ Recent studies have shown that platinum agents possessed activity against tumor and this finding may prove helpful in the development of anticancer metallodrugs. ${ }^{13}$

\section{METAL COMPLEXES OTHER THAN CISPLATIN, AS THERAPEUTIC AGENTS}

Cisplatin is widely used for the treatment and diagnosis of solid carcinomas and is a worthy cytostatic drug. Other metals like copper, iridium, titanium, gold, tin, germanium, bismuth, ruthenium, molybdenum, gallium, rhodium are used as anticancer agents and their history has shown them to be significantly effective against carcinogenic diseases in both humans and animals. In periodic table, groups 3 to 12 represent transition metals, also recognized as $d$ block element due to their half or partially filled d-orbitals. Hence, coordination complexes are made due to partially filled d-subshells. The structure of coordination complex or metal complex contains central metal atom bonded by many ligands that surround the central metal atom. Ligands may be anions or molecules because central metal atom is positively charged. First time the metal conjugates were fabricated in 1875 by Sophus Jorgensen in Denmark. In 1893, Alfred Werner tested various compounds containing chlorine, cobalt and ammonia which were proven a big breakthrough in this regard. Due to his work in 1913, Alfred Werner was awarded with the Noble Prize. ${ }^{14}$ In 1967, Rosenberg did a marvelous work when he investigated bacterial growth under electrical field effect and observed the inhibition of cell division by elongation of bacteria. He obtained the series and found that cisplatin is produced due to platinum electrodes and not due to electric field effect. ${ }^{15}$ These complexes are represented in Figure 4.

The complex was discharged into the medium where it penetrated the cell wall and adducts were formed with DNA, hence discontinuing replication. ${ }^{16}$ The revelation came during an era when small organic molecules were focused and evaluated for anticancer activity. It symbolized the passage of inorganic complexes into the field on account of cisplatin. Cisplatin made remarkable contribution in cancer treatment of testicular cancer, which was previously a deadly disease. ${ }^{17}$ Subsequently, the running mode of efforts prior to cisplatin's revelation, moved its focus to include inorganic complexes and aiming at exploring chemotherapeutic range of cisplatin and enhancing its clinical profile ${ }^{18}$. The serendipity discovery of 
cisplatin proposed that some fruitful change in structure might lead to enhance the activity of metal-based medicines. Now-a-days, platinum based drugs (carboplatin, cisplatin and oxaliplatin) are employed in the approximate range of $50 \%$ $70 \%$ of tumor treatment systems. ${ }^{19}$ Cisplatin and its subsidiaries aren't employed for all type of cancers due to the fact that some tumor types resist the maximum tolerable dosage. Cisplatin-resistant cancer types include breast cancer and prostate cancer where former is the most common type of cancer in European women and latter in men from United States. $^{20}$

\section{THE ROLE OF CHELATES AS THERAPEUTIC AGENTS}

It is well established fact that good health is directly related to the presence of several metal ions in body but on the other hand, recently various metal containing compounds have also been documented as environmental and work-place carcinogens. ${ }^{21,22}$ Many chelates of different metals are utilized as therapeutic agents like $\mathrm{Fe}^{23}{ }^{23} \mathrm{Ir}^{24}$ $\mathrm{Rh}^{25}$ and $\mathrm{Co}^{26}$ etc. In this regards $\mathrm{C}-\mathrm{H}$. Leung et al. reported the activity of iridium and rhodium complexes. ${ }^{27}$ They explained their complexes to be acting as therapeutic agents, protein inhibitors, ${ }^{28}$ especially kinase inhibitors ${ }^{29,} 30$, inhibitors of enzymes like ubiquitin potrase sys (UPS) ${ }^{31}$ and NEDD8-activ enzyme (NAE) ${ }^{32}$ and inhibitors of protein-protein interaction ${ }^{33}$ M.C. Heffern et al. highlighted the role of cobalt as therapeutic agent ${ }^{34}$ and reported that the complexes of cobalt are very reactive towards ligand exchange making bioactive ligand. ${ }^{35}$ Cobalt complexes played a role of bio-reductive agents. ${ }^{36,37}$ In which they explained that cobalt (III) complexes are inert and by reduction they convert into Co (II) which has ability to immediately substitute its ligands. ${ }^{38}$ R.C. Hider et al. successively reported in his review the role of iron chelates as therapeutic agents. They described the disadvantages and advantages of iron chelators. 30 years ago, it was considered that iron chelates are orally inactive but its successful design made it not just orally active but also reduced its toxicity to almost zero level. ${ }^{39}$ D.R. Richardson reported the use of iron chelators as therapeutic agents in his review. ${ }^{40} \mathrm{He}$ also focused on the treatment of cancerous cells with the use of iron chelates. ${ }^{41}$

\section{IMPORTANCE OF METAL COMPLEXES AS MRI AGENTS}

Metal complexes are of great significance as MRI agents when employed as imaging operators. They are also used for various infections such as cerebrum issues and coronary diseases etc. They can not only determine different parts of diseases such as tissue hypoxia but also identify molecular phenomenon such as multidrug resistance. Because metal centers are positively charged, they combine with negative centers of biomolecules (proteins and nucleic acids) and thus particular biological processes become easily understandable including the initiation of thrombi and the imaging of infections. With the help of using methods of system filtration viz. gamma PET and MRI, tissues and organs with radio-labeled compounds can be envisioned and such representation assures the detection of variations from the abnormalities. Radionuclide complexes are utilized for diagnosis, as comparison media and as therapeutic agents. ${ }^{42}$

\section{METAL COMPLEXES AS ANTIMICROBIAL AGENTS}

Many reports demonstrated that the level of microorganisms that resists multi-drugs is increasing continuously ${ }^{43}$ and becoming responsible for ailment problems all over the world ${ }^{4,}{ }^{45}$ like methicillin-resistant Staphylococcus aureus, vancomycini-resistant enterococci, and other drugresistant human pathogens in Europe and United States. ${ }^{46}$ These micro-organisms continue to affect the human race and hence, an effective therapy is needed to cope with them what finally results in the discovery of novel antimicrobial agents. Metal based drugs can replace many other organic drugs which have been conventionally employed for treatment due to the fact that during complexation, synergistic effect is produced between ligand and metal ions. It was reported that numerous metal complexes in antibiotics contain quinoline group e.g. ciprofloxacin, tetracycline and norfloxacin possess more activity than antibiotic alone, for example, it has been recently reported that antimicrobial activity of norfloxacin alone is not enriched but when it undergoes complexation with bismuth (bismuth-norfloxacin complex) shows better antimicrobial activity ${ }^{47}$ Previous studies have shown that the activity is enhanced due to the increase in the bio-availability of complex. It means 
the fabrication of metal complexes facilitates the transport of organic ligands into or towards the bacterial cells. Some palladium complexes have been reported which are very efficient against resistant microorganisms. One of such examples is tetracycline's Pd (II) complex as shown in the Figure 3 which is sixteen times more potent against the tetracycline resistant bacterial strain, E. coli HB101/pBR322, as compared to parent compound. However, Pd (II) complex of doxycycline (Fig. 3) is two times more potent to fight against microorganism than doxycycline. ${ }^{48}$ The report about tin complexes shows its antimicrobial activity such as organotin (IV) complexes with $\mathrm{N}$-alkylisatin bisthiocarbonohydrazones and isatin. ${ }^{49}$ Other metals have also been reported which can be used as antibacterial agents such as mercury and silver salts. ${ }^{50,51}$ In this regard, for many years, copper ions have been known for their antifungal effect. In the practical field the antimicrobial activity of Silver (I) and Copper (II) complexes of 2-pyridyl-1Hbenzimidazoles are known. ${ }^{52}$

Similarly, moderate antimicrobial activity of bismuth compounds is also known but bismuth therapy can enhance the toxicity due to providing short-term effects by large number and frequent dose. Another disadvantage of bismuth is the limiting factor due to its poor solubility in water. It is reported that bismuth complexes show antimicrobial activity towards Gram-negative bacteria and are dependent upon iron uptake. However, iron is necessary for the growth of $H$. pylori. ${ }^{53}$ In treatment of tumors, syphilis, reduction of renal toxicity of cisplatin, in radioisotope therapies etc., bismuth compounds are often used as medicines.

\section{RECENT DEVELOPMENT IN METAL COMPLEXES AS THERAPEUTIC AGENTS}

S. Selvaraj et al. explained the development in the complexation of flavonoid-metal ions based drugs. They declared flavonols more potent than flavones and flavanones. Flavonols easily combine with metal ions and make complexes which possess anti-microbial, anti-cancer, anti- tumor, anti-inflammatory, anti-diabetic and anti-oxidant agents. Flavonoids can make chelates with metal ions and such complexations can interact easily with DNA. Because of their amphiphatic character, they have the ability to combine with DNA and are more suitable for the body as therapeutic agents. ${ }^{54}$ The structure of flavonoid is shown in Figure 5.

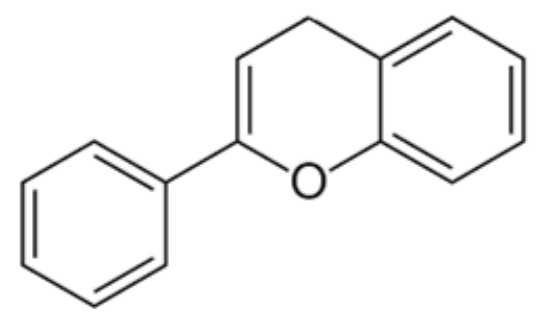

Fig. 5 - Structure of flavonoid.

As it is clear from the figure that flavonoids contain total 3 benzene rings, ${ }^{55}$ and polyphenolic group is basic functional group operating in this structure where opposite to the position of oxygen exists the possibility for another group (either another oxygen or a benzene ring) to attach with this ring. Flavane network has hydrophobic character while hydroxyl group of phenolic region has hydrophilic behavior. So, due to this amphiphilic character flavonoids can play a vital role in the body.

Metal ions makes complex with flavonoids while substituting the hydroxyl group hydrogen. Genistein and quercetin have been reported previously to deprotonate and coordinate with metal atoms. When transition metal atoms combine with flavonoids they invert their properties but in the end stable complexes are formed. The metal complexes formed in the 1:1 and 1:2 as M:L. ${ }^{56-58}$ Reflux condensation method is used for the fabrication of metal ions complexation. ${ }^{59,} 60$ Different flavanoid-metal ion complexes previously reported are enlisted in Table 1.

Table 1

Flavonoid-metal ion complexes

\begin{tabular}{|c|c|c|c|c|}
\hline $\begin{array}{l}\text { Sr. } \\
\text { No. }\end{array}$ & Flavonoids & $\begin{array}{l}\text { Metal } \\
\text { ions }\end{array}$ & Therapeutic activity & References \\
\hline 1 & Genistein & $\mathrm{Cu}(\mathrm{II})$ & Anti-oxidant activity & 61 \\
\hline 2 & Quercetin & $\begin{array}{l}\mathrm{Cu}(\mathrm{II}) \\
\mathrm{Co}(\mathrm{II})\end{array}$ & $\begin{array}{l}\text { Anti-oxidant, }{ }^{21} \text { anti-tumor, }{ }^{2} \text { and DNA-binding activity }{ }^{25} \\
\text { Anti-tumor and anti-oxidant activity }\end{array}$ & $\begin{array}{l}62,63 \\
64\end{array}$ \\
\hline
\end{tabular}


Similarly, flavanones, flavones and flavonols can coordinate with metal atoms and are employed as therapeutics such as anti-inflammatory, antioxidants, antitumor, interacting with DNA, anticancer, antimelanoma and antiosteogenic agents. Following metal atoms: $\mathrm{Cu}(\mathrm{II}), \mathrm{Ni}(\mathrm{II})$, $\mathrm{Fe}(\mathrm{II}), \mathrm{Zn}(\mathrm{II}), \mathrm{Co}(\mathrm{II}), \mathrm{Cd}(\mathrm{II}), \mathrm{Pt}(\mathrm{II}), \mathrm{Mo}(\mathrm{II}), \mathrm{Pd}(\mathrm{II})$, $\mathrm{Mn}(\mathrm{II}), \mathrm{Hg}(\mathrm{II}), \mathrm{Lu}(\mathrm{III}), \mathrm{La}(\mathrm{III}), \mathrm{Gd}(\mathrm{III}), \mathrm{Al}(\mathrm{III})$, $\mathrm{Fe}(\mathrm{III}), \mathrm{Eu}(\mathrm{III})$ and VO(IV) majorly form complex with flavonoids. ${ }^{65-75}$

\section{FUTURISTIC \\ ANTICANCER METAL COMPLEXES}

Mainly platinum based metal drugs are found but there are number of other metal atoms which are part of drugs and successfully employed in the field of medicine as therapeutic agents. Much advancement has been reported recently and other studies attempt to link the future of anticancer metal complexes to the treatment of tumour metasis as well. ${ }^{76}$ Few key advancements are discussed in this study.

\section{Iron complexes}

Iron complexes are essential to our body as they perform various functions and activities in our body such as cell growth and DNA interaction and proliferation. ${ }^{77}$ Ferrocenium trichloroacetate and ferrocenium picrate salts are the earliest known iron complexes. These complexes are successfully used for the generation of ROS ("reactive oxygen species") which is used in curing damaged DNA. Figure 7 shows the structures of iron complexes. ${ }^{78}$

Moreover, there are recent advancements such as the fabrication of Fe (II, III) poly-pyridyl and ferrocenyl based complexes. ${ }^{79,} 80$ GonzalezBartulos et al. fabricated five Fe (II) complexes of aminopyridine to be anticancer ones and these complexes are shown in Figure $7 .{ }^{81}$

Few of the significant recently developed iron (III) complexes are enlisted in the Table 2.

\section{Ruthenium complexes}

Ruthenium is amongst the last in the list according to abundance but due to its corrosion resistance, variety in oxidation states, antimetastatic property and excellent stability; it gains a lot of attention worldwide. It is also employed as an antitumor therapeutic agent. ${ }^{84}$ Some recently developed complexes of ruthenium with similar bioactivity such as cytotoxic, antineoplastic and anticancer properties are enlisted in the Table 3.

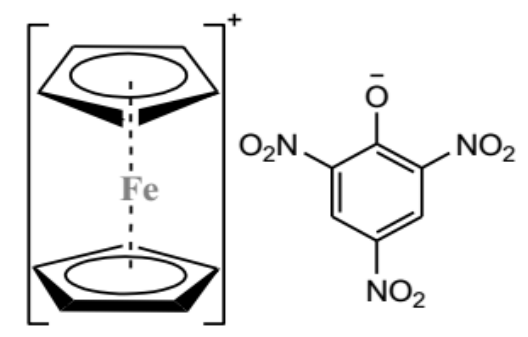

Ferrocenium picrate

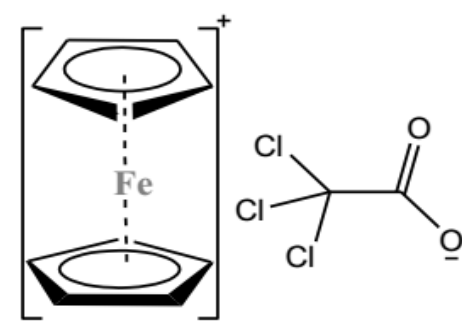

Ferrocenium trichloroacetate

Fig. 6 - Earliest known Fe complexes.
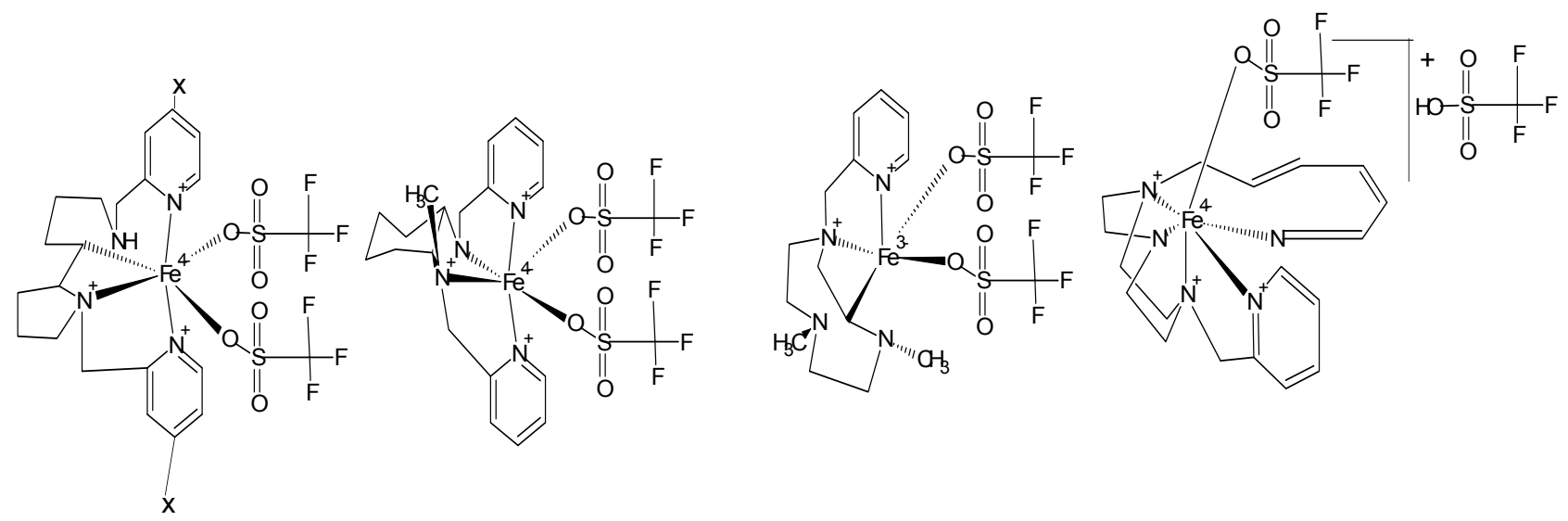

Fig. 7 - Fe (II) complexes. 


\section{Table 2}

Recent complexes of iron

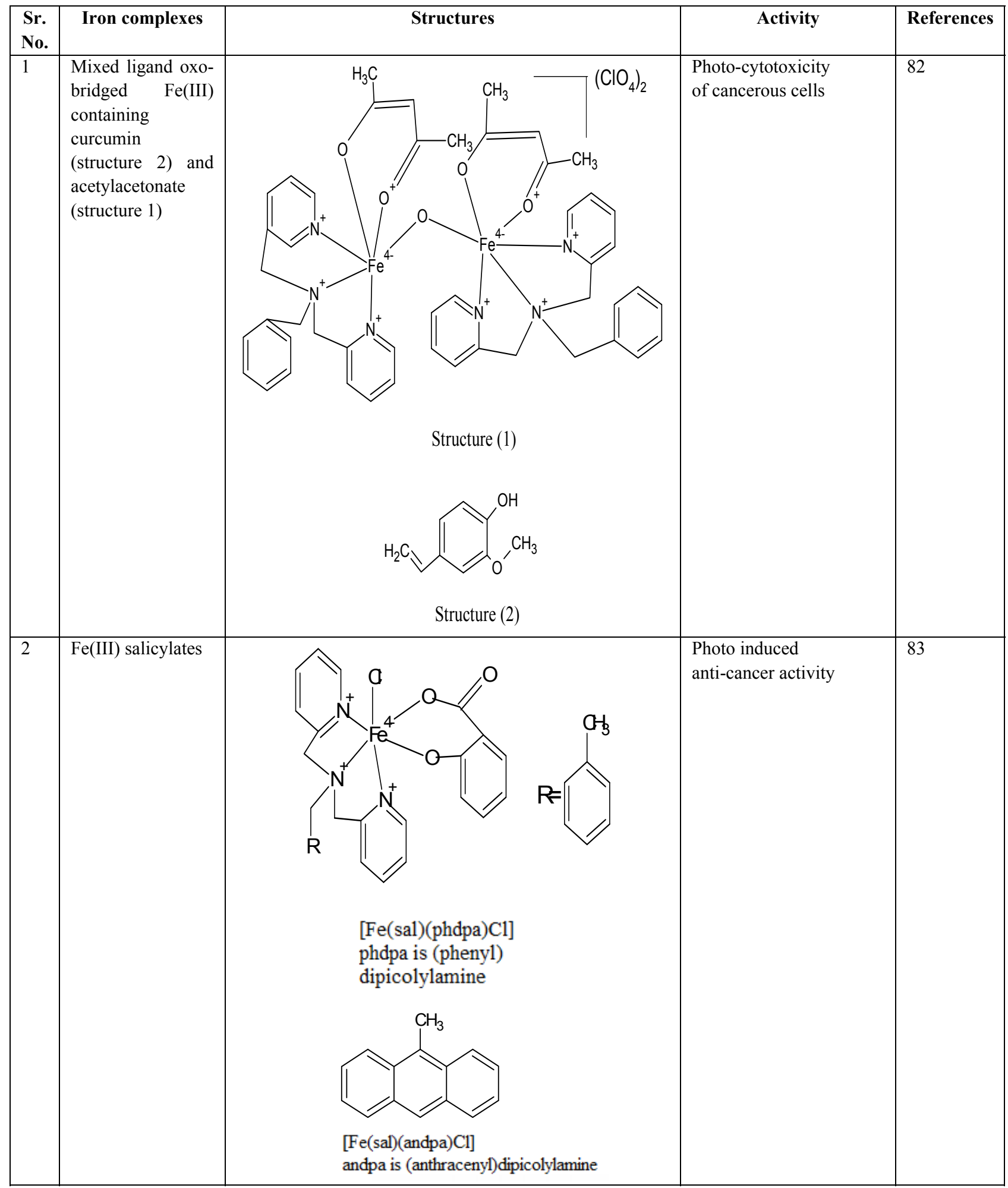


Table 3

Recently developed ruthenium complexes

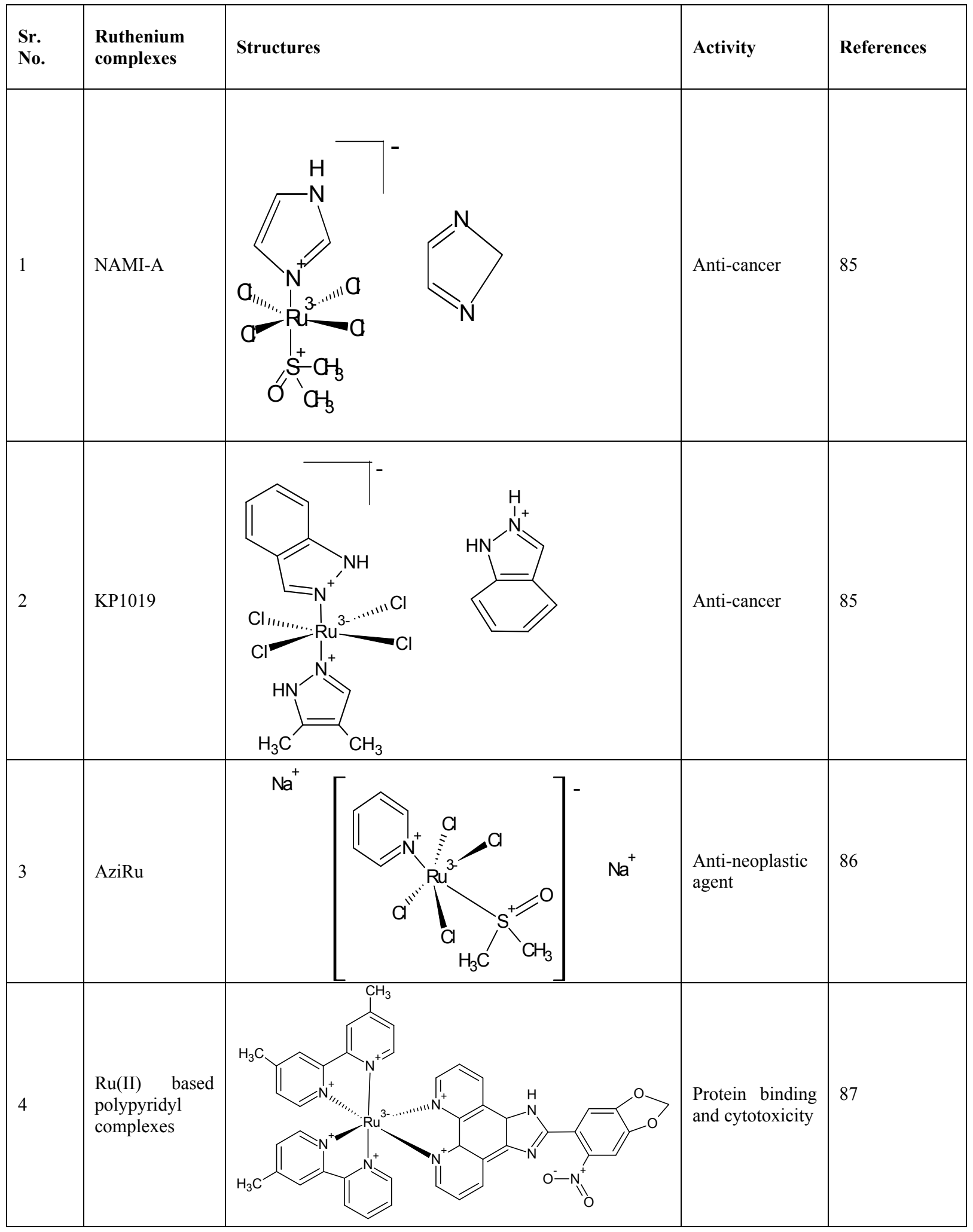




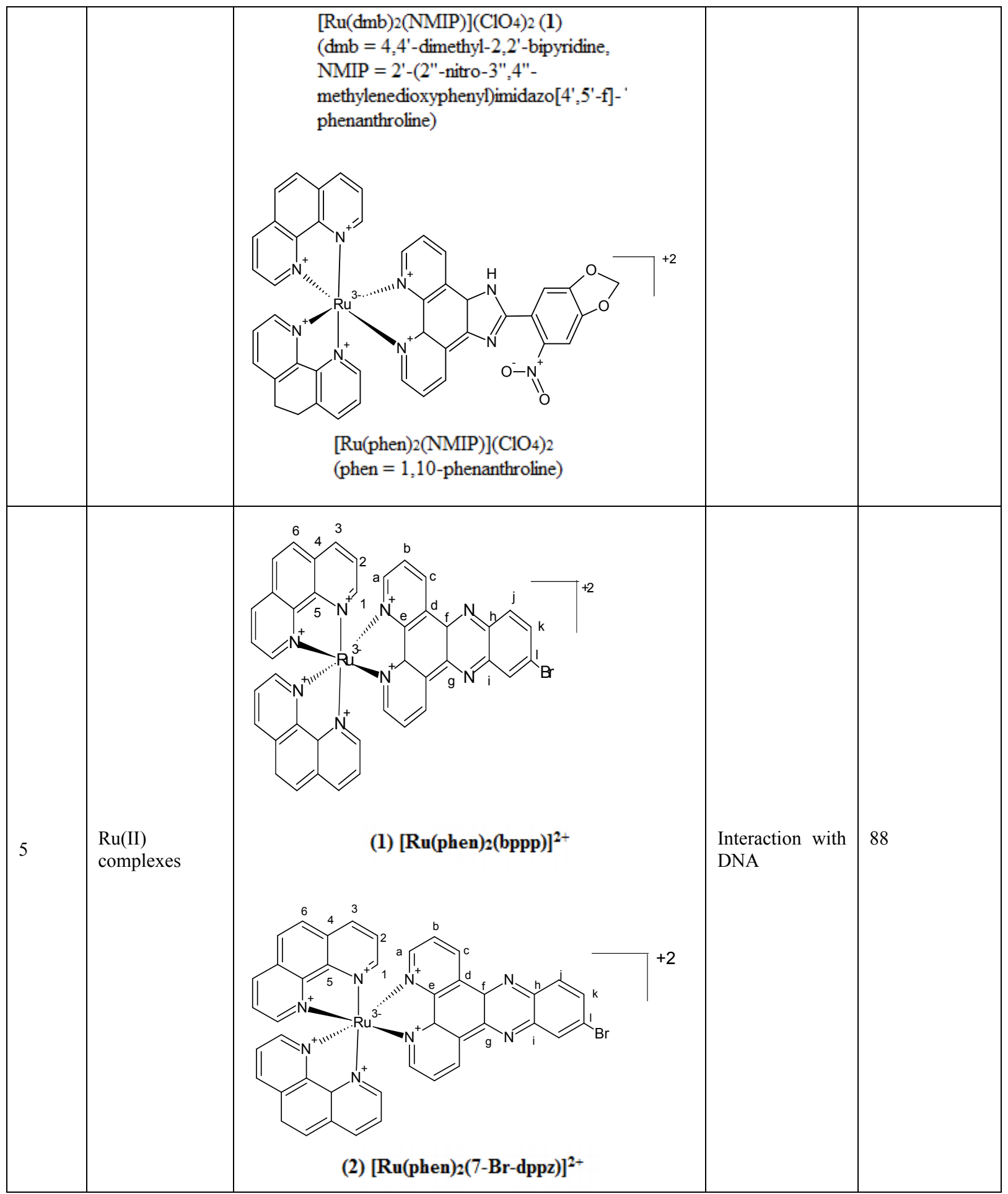

\section{Palladium complexes}

Palladium complexes are also categorized among those which are used as therapeutic agents. $\mathrm{Pd}$ (II) complexes exhibit almost the same chemical properties as cisplatin does ${ }^{89}$ but studies revealed $\mathrm{Pd}$ (II) complexes to possess better stability, greater solubility and they are kinetically more labile. ${ }^{90}$ Their coordination chemistry is also similar to Pt (II). ${ }^{91}$ Recently synthesized complexes of $\mathrm{Pd}(\mathrm{II})$ are mentioned in Table 4.

\section{Other metal complexes}

Osmium complexes are more like ruthenium complexes. R. J. Mcquitty evaluated complexes of these metals to have the same effect if monodentate leaving group is altered. ${ }^{94}$ But kinetics and 
mechanisms of reactions occur differently due to the fact that osmium and ruthenium are different. Osmium complexes have more potential than ruthenium against cancer cells and their complexes are effective as they easily make linkage with DNA that leads towards the generation of ROS which destroys or damage cancer cells. ${ }^{95,96}$
Silver and gold complexes also possess antimicrobial properties where silver is used in the form of silver nitrate $\left(\mathrm{AgNO}_{3}\right) \cdot{ }^{97}$ Being less toxic in nature, it is used to cure burns. Its complex, silver sulfadiazine is shown in Figure 8 that serves such purpose.

Table 4

Recently developed complexes of Pd(II)

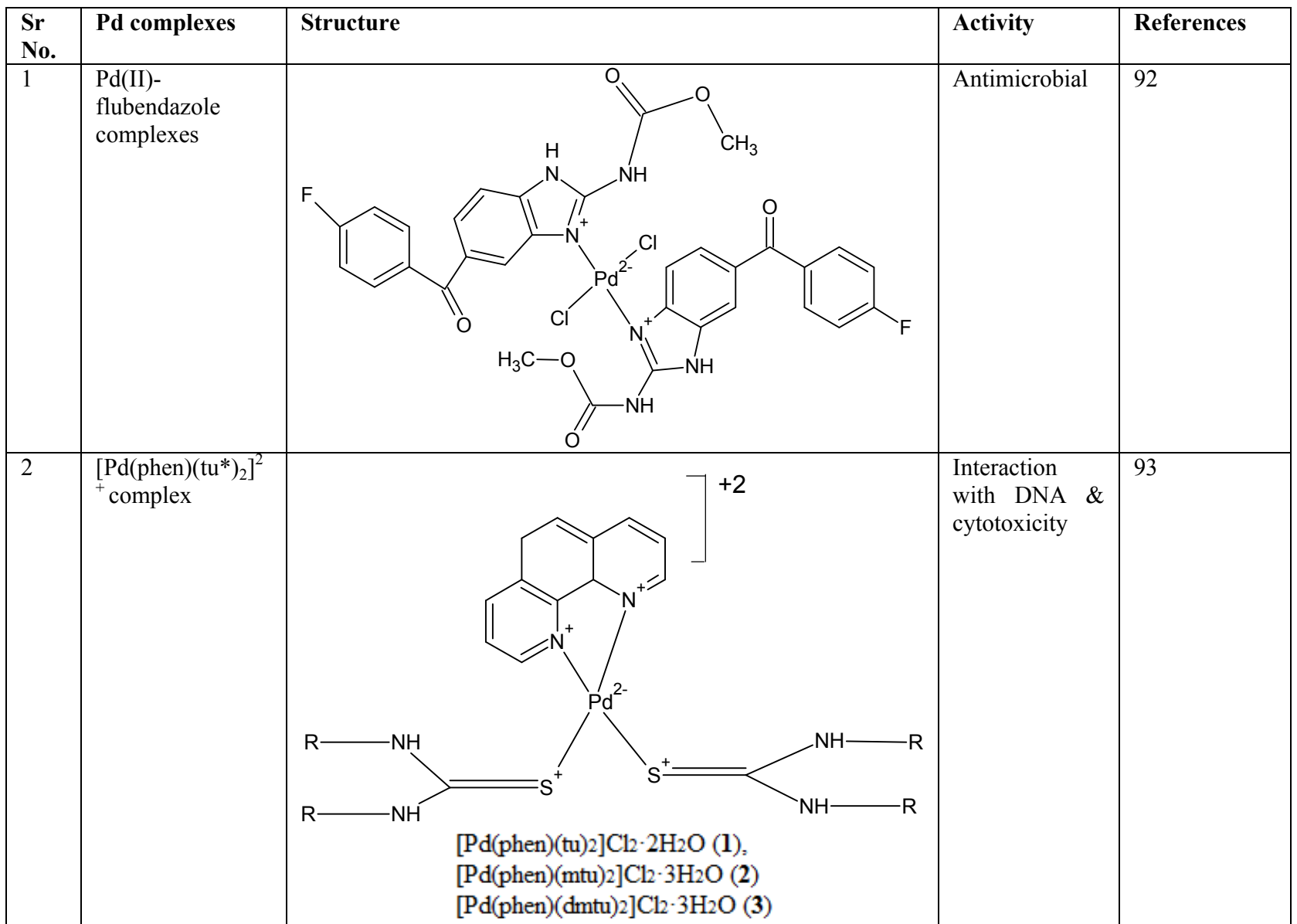

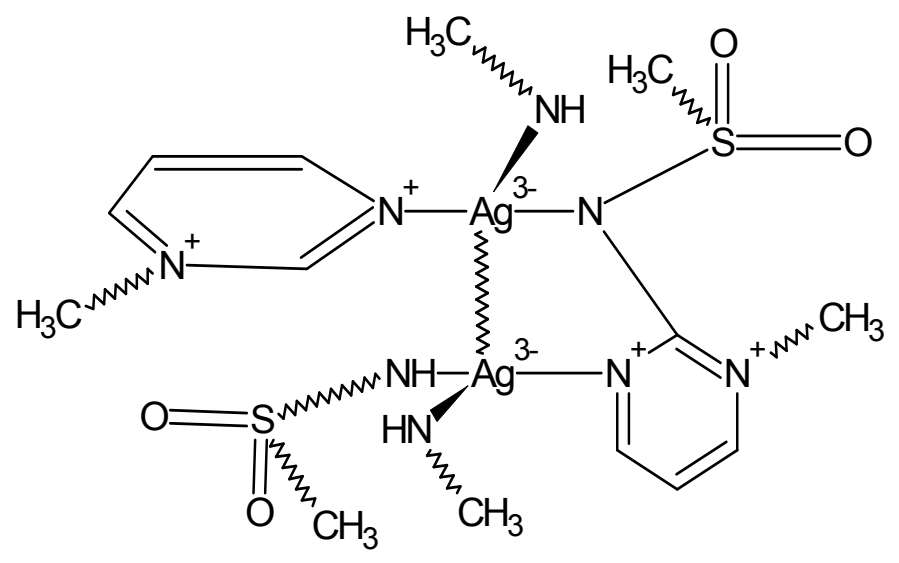

Fig. 8 - Silver sulfadiazine. 


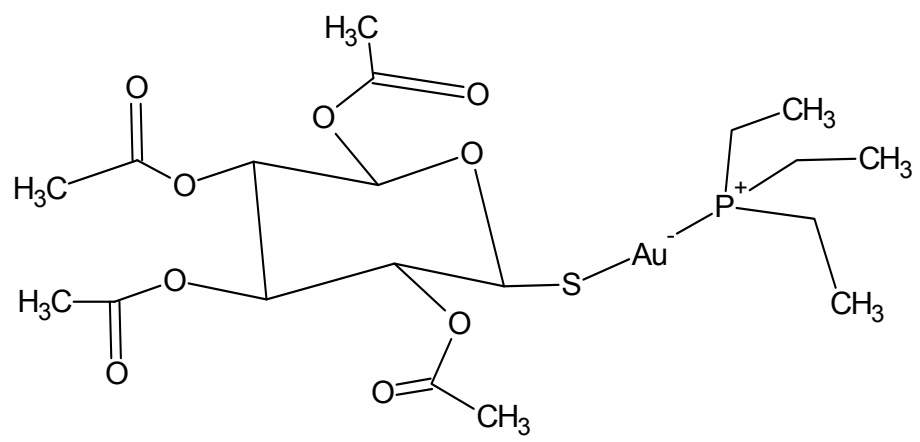

Fig. 9 - Auranofin structure.

Furthermore, silver complexes are vastly used, almost in every field of life such as foods, shoe insoles, bandages, surgical instruments and cutlery. ${ }^{98-100}$ Although, gold is more expensive than silver metal yet its benefits in the field of medicines as antimicrobial and therapeutic agents, has increased its importance to a great deal. In the treatment of rheumatoid arthritis, gold complexes are employed. Auranofin complex of aurum is used to generate haeme oxygenase- 1 and ROS. ${ }^{101}$ Both of these are used as anticancer agents.

\section{CONCLUSION}

In this study, an outline of the metal based drugs which have either demonstrated promising results or utilized as a part of the treatment of various diseases and so forth, has been displayed. It appears that open doors exist to endeavor metal and metal based drugs in the revelation and advancement of novel chemotherapeutic agents. The strengthened after-effects of pre-clinical and clinical studies with metal compounds structure the premise for further examinations towards the improvement of metallo-drugs for better medicinal services. Further, comprehension of component of activity, cell target and the approximately composed metal complexes will expand the selectivity and the specificity of new metal complexes. In simple words, metal complexes offer new properties that can't be found amongst natural specialists. The helpful utilization of therapeutic agents of metal complexes is still an unexplored region of research and proceeding with work here is justified. Because of a wide assortment of coordination spheres, oxidation states, redox potential and ligand design, coordination and organometallic compounds can efficiently adjust the thermodynamic and kinetic properties of the metallodrug complexes towards biological receptors. In this manner, they offer opportunities to design novel agents for the treatment of various different diseases.

\section{REFERENCES}

1. M. Gielen and E. R. Tiekink, "Metallotherapeutic drugs and metal-based diagnostic agents: the use of metals in medicine", John Wiley \& Sons., 2005.

2. Y. Yan, J. Zhang, L. Ren and C. Tang, Chem. Soc. Rev., 2016, 45, 5232-5263.

3. D. Gaynor and D. M. Griffith, Dalton Trans., 2012, 41, 13239-13257.

4. A. Sigel, H. Sigel and R. K. Sigel, "The Alkali Metal Ions: Their Role for Life", Springer, 2016.

5. K. H. Thompson, Encyc. Inorg. Bioinorg. Chem., 2011.

6. K. H. Thompson and C. Orvig, Science, 2003, 300, 936939.

7. J. Fraser and M. Reed, Can. Assoc. Radiol. J., 2013, 64, 82-84.

8. P. Ehrlich and A. Bertheim, Eur. J. Inorg. Chem., 1912, 45, 756-766.

9. N. C. Lloyd, H. W. Morgan, B. K. Nicholson and R. S. Ronimus, Angew. Chem. Int. Ed., 2005, 44, 941-944.

10. F. Chast, C. G. Wermuth, J. P. Kan, J.P. Gies, Y. Landry, D. Newman and A. Wagner, Practice Med. Chem., 2008, 3-28.

11. R. Y. Tsang, T. Al-Fayea and H. J. Au, Drug Saf., 2009, 32, 1109-1122.

12. J. H. Burchenal, K. Kalaher, K. Dew, L. Lokys and G. Gale, Biochimie., 1978, 60, 961-965.

13. R. A. Alderden, M. D. Hall and T. W. Hambley, $J$. Chem. Educ., 2006, 83, 728.

14. S. Rafique, M. Idrees, A. Nasim, H. Akbar and A. Athar, Biotechnol. Mol. Biol. Rev., 2010, 5, 38-45.

15. R. W. Fleischman, S. W. Stadnicki, M. F. Etheir and U. Schaeppi, Toxicol. Appl. Pharmacol., 1975, 33, 320-332.

16. ***L. C. Richardson, A. J. Neri, E. Tai and J. D. Glenn, "Urologic Oncology: Seminars and Original Investigations" Elsevier, 2012, 30, 95-101.

17. P. J. Dyson and G. Sava, Dalton Trans., 2006, 16, 19291933.

18. C. S. Allardyce and P. J. Dyson, Dalton Trans., 2016, 45, 3201-3209.

19. V. Brabec and J. Kasparkova, Drug Resist. Update., 2005, 8, 131-146.

20. E. N. Drake and H. H. Sky-Peck, Cancer Res., 1989, 49, 4210-4215.

21. R. L. Nelson, J. C. Tanure and G. Andrianopoulos, Dis. Colon Rectum., 1987, 30, 947-949. 
22. M. A. Atkinson and N. K. MacLaren, Sci. Am., 1990, 263, 62-70.

23. Y. Shechter, Diabetes, 1990, 39, 1-5.

24. C. Das, P. Kulkarni, A. Constantinescu, P. Antich, F. Blattner, and P. Tucker, Proc. Natl. Acad. Sci., 1992, 89, 9749-9753.

25. K. Tungsanga and P. Sriboonlue, Int. J. Epidemiol., 1993, 22, 81-87.

26. C. H. Leung, H. J. Zhong, D. S. H. Chan and D. L. Ma, Coordin. Chem. Rev., 2013, 257, 1764-1776.

27. E. Meggers, Chem. Commun., 2009, 9, 1001-1010.

28. I. Melnikova and J. Golden, Nat. Rev. Drug Discov., 2004, 3, 993-994.

29. P. Cohen, Nat. Rev. Drug Discov., 2002, 1, 309-315.

30. F. Bernassola, A. Ciechanover and G. Melino, Cell Death Differ., 2010, 17, 1.

31. H. J. Zhong, H. Yang, D. S. H. Chan, C. H. Leung, H. M. Wang and D. L. Ma, PLoS One, 2012, 7, 49574.

32. C. H. Leung, H. J. Zhong, H. Yang, Z. Cheng, D. S. H. Chan, V. P. Y. Ma, D. L. Ma, Angew. Chem. Int. Ed., 2012, 51, 9010-9014.

33. M. C. Heffern, N. Yamamoto, R. J. Holbrook, A. L. Eckermann and T. J. Meade, Curr. Opin. Chem. Biol., 2013, 17, 189-196.

34. J. A. Schwartz, E. K. Lium and S. J. Silverstein, J. Virol., 2001, 75, 4117-4128.

35. M. D. Hall, T. W. Failes, N. Yamamoto and T. W. Hambley, Dalton Trans., 2007, 36, 3983-3990.

36. N. Graf and S. J. Lippard, Adv. Drug Deliv. Rev., 2012, 64, 993-1004.

37. T. W. Hambley, Dalton Trans., 2007, 43, 4929-4937.

38. T. Zhou, Y. Ma, X. Kong and R. C. Hider, Dalton Trans., 2012, 41, 6371-6389.

39. D. Richardson, Crit. Rev. Oncol. Hematol., 2002, 42, 267-281.

40. F. Wang, R. Elliott and J. Head, Anticancer Res., 1998, 19, 445-450.

41. S. K. Bharti and S. K. Singh, Der Pharm. Lettre, 2009, 1, 39-51.

42. S. Harbarth, W. Albrich, D. A. Goldmann and J. Huebner, The Lancet Infect. Dis., 2001, 1, 251-261.

43. L. A. Mitscher, S. P. Pillai, E. J. Gentry and D. M. Shankel, Med. Res. Rev., 1999, 19, 477-496.

44. A. Bagheri, Pharm. Chem. J., 2015, 48, 765-769.

45. P. Viksveen, Homeopathy, 2003, 92, 99-107.

46. A. R. Shaikh, R. Giridhar and M. R. Yadav, Int. j. Pharm., 2007, 332, 24-30.

47. W. Guerra, E. de Andrade Azevedo, A. R. de Souza Monteiro, M. Bucciarelli-Rodriguez, E. Chartone-Souza, A. M. A. Nascimento and E. C. Pereira-Maia, J. Inorg. Biochem., 2005, 99, 2348-2354.

48. A. Bacchi, M. Carcelli, P. Pelagatti, G. Pelizzi, M. C. Rodriguez-Arguelles, D. Rogolino, C. Solinas and D. F. Zani, J. Inorg. Biochem., 2005, 99, 397-408.

49. A. Russell and W. Hugo, Prog. Med. Chem., 1994, 31, 351-370.

50. A. Gupta, K. Matsui, J.-F. Lo and S. Silver, Nat. Med., 1999, $5,183-188$.

51. Z. H. Chohan, Appl. Organomet. Chem., 2006, 20, 112-116.

52. L. Zhang, K. Y. Szeto, W. B. Wong, T. T. Loh, P. J. Sadler and H. Sun, Biochemistry, 2001, 40, 13281-13287.

53. G. G. Briand and N. Burford, Chem. Rev., 1999, 99, 2601-2658.

54. S. Selvaraj, S. Krishnaswamy, V. Devashya, S. Sethuraman, and U. M. Krishnan, Med. Res. Rev., 2014, 34, 677-702.
55. B. H. Havsteen, Pharmacol. ther., 2002, 96, 67-202.

56. W. Chen, S. Sun, Y. Liang and J. Song, J. Mol. Struct., 2009, 918, 194-197.

57. A. Pękal, M. Biesaga and K. Pyrzynska, Biometals, 2011, 24, 41-49.

58. S. Dowling, F. Regan and H. Hughes, J. Inorg. Biochem., 2010, 104, 1091-1098.

59. M. Tan, J. Zhu, Y. Pan, Z. Chen, H. Liang, H. Liu and H. Wang, Bioinorg. Chem. Appl., 2009.

60. R. Pereira, N. E. Andrades, N. Paulino, A. C. Sawaya, M. N. Eberlin, M. C. Marcucci and S. P. Bydlowski, Molecules, 2007, 12, 1352-1366.

61. S. Dowling, F. Regan and H. Hughes, J. inorg. biochem., 2010, 104, 1091-1098.

62. S. B. Bukhari, S. Memon, M. Mahroof-Tahir and M. I. Bhanger, Spectrochim. Acta. A. Mol. Biomol. Spectrosc., 2009, 71, 1901-1906.

63. J. Tan, B. Wang and L. Zhu, J. Biol. Inorg. Chem., 2009. 14, 727-739.

64. S. B. Bukhari, S. Memon, M. M. Tahir and M. I. Bhanger, J. Mol. Struct., 2008, 892, 39-46.

65. M. S. Ska-Kordala, A. B. Kowska, J. O. Ski and J. Gabrielska, Cel. Mol. Bio. Lett., 2001, 6, 277-281.

66. V. A. Kostyuk, A. I. Potapovich, E. N. Strigunova, T. V. Kostyuk and I. B. Afanas' ev, Arch. Biochem. Biophys., 2004, 428, 204-208.

67. V. Kuntić, I. Filipović and Z. Vujić, Molecules, 2011, 16, 1378-1388.

68. V. Uivarosi, S. F. Barbuceanu, V. Aldea, C. C. Arama, M. Badea, R. Olar and D. Marinescu, Molecules, 2010, 15, 1578-1589.

69. D. Malešev and V. Kuntić, J. Serb. Chem. Soc., 2007, 72, 921-939.

70. R. F. De Souza and W. F. De Giovani, Redox Rep., 2004, 9, 97-104.

71. S. Sungur and A. Uzar, Spectrochim. Acta. A. Mol. Biomol. Spectrosc., 2008, 69, 225-229.

72. J. Tan, L. Zhu and B. Wang, Dalton Trans., 2009, 24, $4722-4728$

73. S. M. Ahmadi, G. Dehghan, M. A. Hosseinpourfeizi, J. E. N. Dolatabadi and S. Kashanian, DNA Cell biol., 2011, 30, 517-523.

74. A. Bravo and J. R. Anacona, Transit. Metal Chem., 2001, 26, 20-23.

75. K. Durgo, I. Halec, I. Šola and J. Franekić, Arch. Ind. Hyg. Toxicol., 2011, 62, 221-227.

76. A. Bergamo and G. Sava, Chem. Soc. Rev., 2015, 44, 8818-8835.

77. S. V. Torti and F. M. Torti. Nat. Rev. Cancer, 2013, 13, 342-35-0.

78. P. Köpf-Maier, H. Köpf and E. W. Neuse. J. Cancer Res. Clin. Oncol., 1984, 108, 336-342.

79. M. J. Hannon, Pure Appl. Chem., 2009, 25, 24-32.

80. I. Ott and R. Gust. Arch. Pharm., 2007, 340, 117-125.

81. M. González-Bártulos, C. Aceves-Luquero, J. Qualai, O. Cussó, M. A. Martínez, S. F. de Mattos and A. Massaguer, PloS one, 2015, 10, e0137800.

82. T. Sarkar, R. J. Butcher, S. Banerjee, S. Mukherjee and A. Hussain, Inorg. Chim. Acta, 2016, 439, 8-21.

83. A. Garai, I. Pant, P. Kondaiah and A. R. Chakravarty, Polyhedron, 2015, 102, 668-679.

84. G. Sathyaraj, T. Weyhermüller and B. U. Nair, Eur. J. Med. Chem., 2010, 45, 284-298.

85. F. Lentz, A. Drescher, A. Lindauer, M. Henke, R. A. Hilger, C.G. Hartinger, M. E. Scheulen, C. Dittrich, B. K. Keppler and U. Jaehde, Anti-Cancer Drugs, 2009, 20, 97 109. 
86. G. Mangiapia, G. D'Errico, L. Simeone, C. Irace, A. Radulescu, A. Di Pascale, A. Colonna, D. Montesarchio and L. Paduano, Biomaterials, 2012, 33, 3770-3779.

87. S. H. Liu, J. W. Zhu, H. H. Xu, Y. Wang, Y. M. Liu, J. B. Liang, G. Q. Zhang, D. H. Cao, Y. Y. Lin and Y. Wu, Spectrochim. Acta, Part A, 2016, 161, 77-86.

88. N. Deepika, C. S. Devi, Y. P. Kumar, K. L. Reddy, P. V. Reddy, D. A. Kumar, S. S. Singh and S. Satyanarayana, J. Photochem. Photobiol., B, 2016, 160, 142-151.

89. H. Mansouri-Torshizi, M. Saeidifar, A. Divsalar and A. A. Saboury, Nucleos, Nucleot Nucl, 2011, 30, 405-412.

90. A. Garoufis, S. K. Hadjikakou and N. Hadjiliadis, Coord. Chem. Rev., 2009, 253, 1384-1396.

91. M. Fanelli, M. Formica, V. Fusi, L. Giorgi, M. Micheloni and P. Paoli, Coord. Chem. Rev., 2016, 310, 41-54.

92. A. M. Mansour, E. M. E. Bakry and N. T. Abdel-Ghani, J. Iran. Chem. Soc., 2016, 13, 1429-1437.
93. C. V. Barra, F. V. Rocha, L. Morel, A. Gautier, S. S. Garrido, A. E. Mauro, R. C. G. Frem and A. V. G. Netto, Inorg. Chim. Acta, 2016, 446, 54-60.

94. R. J. McQuitty, Sci. Prog., 2014, 97, 1-19.

95. S. H. Van Rijt, A. Mukherjee, A. M. Pizarro and P. J. Sadler, J. Med. Chem., 2010, 53, 840-849.

96. S. H. Van Rijt, H. Kostrhunova, V. Brabec and P. J. Sadler, Bioconj. Chem., 2011, 22, 218-226.

97. J. L. Clement and P. S. Jarrett, Met. Based. Drugs, 1994, $1,467-482$.

98. A. Martínez-Abad, G. Sánchez, J. M. Lagaron, and M. J. Ocio, Food Chem., 2013, 139, 281-288.

99. S. Thomas and P. McCubbin, J. Wound Care, 2003, 12, 101-107.

100. L. Taylor, P. Phillips and R. Hastings, J. Infect. Prev., 2009, 10, 6-12.

101. N. H. Kim, M. K. Oh, H. J. Park and I. S. Kim, J. Pharmacol. Sci., 2010, 113, 246-254. 
